\title{
The Cultural Exception: Why?
}

\author{
By Anthony J. Liehm \\ Fall 1996 Issue of KINEMA
}

THE NEXT CENTURY will definitely be a century of the audio-visual, an alpha-numeric century. This will have an enormous impact on culture. In every household, of whatever might then be called the developed world, there will be a huge TV screen and a smaller one in each room. Add the internet and other advances technology will offer and you will easily agree that, whether we like it or not, the audio-visual media will play the role of the most important, dominant vectors of art and culture. Furthermore, the attitude towards these developments of still too many intellectuals and artists -- one of hostility and snubbing the audio-visual instead of trying to influence it and occupy an increasingly important position in its structures and programs -- seems a suicidal one. These are the reasons why the Europeans fight for a "cultural exception" to the GATT agreements on free trade concerning the audio-visual domain acquires an enormous importance, at least for the foreseeable future.

We should understand that the United States and Europe (as well as Canada, in a different way) are from the outset placed in different starting blocs. Not only economically, but in the first place due to their traditions and the basic character of their cultures.

Since the very beginning of their history, the European cultures in general and the arts in particular were aimed at a certain elite and were generated from this elite. It took decades, even centuries, before these creations reached larger (but still fairly restricted) audiences, crossing the social boundaries only with difficulty and stubbornly preserving their particular, local, and in many cases national character.

The American culture and arts have had a very different history. Since their origins they were aimed at a popular audience, composed of immigrants from all parts of the world. They took them into their band wagons in the pursuit of their "manifest destiny," that is crossing the continent, in conditions radically different from those in which European culture and arts were created and consumed. And more importantly, most of these immigrants wanted to become Americans, as quickly as possible, and adopted, with a lesser or greater success, a common vernacular, a shared language -- it is only in the second half of this century that some more significant linguistic barriers began to reappear again. Finally, it should not be forgotten that even the privileged classes of the American society -- like the southern aristocracy or the urban upper middle class -- were in their habits, their taste and their general culture much closer to the immigrant masses than to the corresponding social strata within the European nations.

It is on these premises that the United States developed through three centuries a tradition of a mass culture unique in the world, aimed at everybody, understandable to all, with a very small common denominator, and brought it close to the non-American masses throughout the world. This tradition is the very source of the indisputable quality of the American mass culture which succeeded in integrating its many different confluents into a mainstream of unequalled authenticity. And it is exactly this authenticity of the American mass culture -- highly appreciated around the world by different audiences, including the most sophisticated ones -- that cannot be imitated (I firmly believe that a film such as Schindler's List could only be made in America, by an American director).

Exactly this is also the secret of the miracle of Hollywood and, to an ever larger extent, of the American television. Film and television were never conceived there as culture in the narrow sense of the word, but almost exclusively as popular entertainment, aimed at everybody and reflecting the dreams and the truth of all, without inferiority complexes and with a great craftsmanship and savoir-faire.

On the other side of Atlantic, and with only a few exceptions, the European mass culture -- or better "mass cultures" -- will never be aimed at everybody, will never be able to become the truth and the dream of all. Their common denominator is too high and all the attempts to diminish it have been wooed to failure, being most ridiculous for their lack of authenticity. Even French so-called mass culture will always appeal just to the French, the German one to the Germans, etc. 
This is the reason -- and the more in the field of the audio-visual productions aimed primarily at Mister Everybody -- why the European mass products do not stand any chance against similar US productions within an unlimited free market competition in Europe, and even less in America. Let us take just one example, of the British film master named Charlie Chaplin. As long as his genius enriched the American mass culture, he was a great success. However, as soon as he attempted -- beginning with his Modern Times (1936) -- to raise the common denominator of his films, his universal popularity was over. It is this reason, in the first place, and not because of politics, that the American audiences turned their backs on him. All that of course does not apply only to the domain of the audio-visual: Did you ever ask yourselves why the American best-selling popular literature has been as popular in Europe at it is in America, but not at all the other way round?

It is on these grounds why a cultural exception to the GATT agreements is absolutely vital for the survival of authentic European cultures, mainly in the realm of the audio-visual. It will be necessary to persuade the Americans that this is not a French or a European ploy based upon some primitive anti-Americanism. This argument is so obviously one of the bad faith that it does not deserve to be discussed. The fact is that there is a real problem of cultural identity. Some people in Europe sincerely believe that you could promote authentically European audio-visual productions, able to conquer to American market. There are even those, on both sides of the Atlantic, who believe that to do so it would be sufficient to shoot in English -- or at least to dub into English. A certain André, Mulligan from Washington D.C. summed up this way of thinking some time ago in the French weekly L'Express: "... Instead of attacking the American imports -he wrote -- the Europeans should turn the tide and start exporting their productions into the whole world... What Filipacchi (the French press mogul) did with the journal ELLE is an excellent example. Another one is provided by the success of the British Journal The Economist in America." Any comment on this fallacy seems superfluous. But we can extrapolate from it how different the American concept of culture is, compared to the European one.

In fact, European audio-visual productions originating in their own cultures do not stand any chance to conquer more than a marginal share of the American market. That is, the few specialized theatres in a few big American cities, and a few TV programs, aired mostly at night and by cable. Their audiences will always remain limited to those few interested in foreign cultures. No comparison to the multi-million crowds which in Europe and elsewhere are the consumers of the American mass culture. No comparison, too, in terms of distributors' interest and of revenues. Clearly, European audio-visual cultures cannot live off the world market, and must therefore be subsidized.

But why is it that Europeans could not produce films and TV programs appealing to audiences attached to the American productions? Such a situation would presuppose artificial, unnatural, glued-together multinational productions turning out shows with a very low common denominator, without any specific national or regional identity. In most of the cases the result would be just a pale copy of the products of the American mass culture, without their inherent authenticity, ${ }^{(1)}$ their truthfulness. Those craving after such productions are just calling for the abandonment of all cultural identity as it has been understood in Europe for centuries.

Heinrich von Kleist observed in his essay "On Marionette Theatre:" "...To the extent to which conscious reflection becomes dimmer and weaker, grace becomes more resplendent and dominant... When knowledge has, in a manner of speaking, passed through an infinity does grace reappear; so that at the same time it appears in its purest form in that human bodily structure which has either no consciousness at all, or an infinite consciousness, i.e. in the mechanical figure, or in the godhead."

If we one day comprehend that the American culture and civilization are not just an extension of the European ones beyond the ocean but a very different culture and civilization, the mutual understanding will improve and the mutual reproaches -- e.g. "why are you not like me, why can't you understand, it is so simple?" -- will cease. Not only in the realm of culture.

But let us get back to Europe. The European cultural tradition is -- as already mentioned -- of a rather particular kind. It was always generated by cultural elites, aimed at them, and transmitted to larger shifts of the population only progressively and after some time has elapsed. This originally elitist cultural heritage constitutes nevertheless the backbone of the European cultural tradition, even in such domains as religion, folklore, music, eating habits, manners -- and more generally daily life. 
Through centuries this elitist culture was unable to live off the market; it had to be subsidized -- and it was subsidized. The linguistic or ethnic markets for culture were small, the consumers few, the means of cultural communication limited. The sponsors of culture and cultural activities had thus been, since times immemorial, the rulers, the cities, the church, and eventually the nation-states. All of those must be regarded as public institutions and their actions as public funding. Thus the public funding is one of Europe's cultural traditions. Exceptions appeared in most cases rather late, primarily in Protestant countries. But even there it became progressively evident that the multifaceted, multilingual character of European cultures requires not only private but also public help if they have to prosper, or even survive.

This tradition has been recently contested and it becomes more and more urgent to analyze its different aspects on the eve of the twenty-first century.

In fact, is there a European culture? And if so, what is it?

As in any culture, culture in Europe is rooted in history and historical experience. In a certain way, this history and these experiences are often shared by all European nations. While the American history is basically a success story, the European one is a succession of tragedies. ${ }^{(2)}$ This experience constitutes the common denominator of European cultures, each of them, at the same time, being rooted deeply in a history of its own.

How should a cultural policy be formulated or conceived, when there is no common language at the common denominator uniting those different cultures is rather high?

First, we must attempt to describe the particularity of European culture, that is, its distinction form the American, African, and Asian ones. The "europeanity" of the different European cultures will thus become evident. It will also become apparent that one of its particularities is their diversity confronted with the paradigm previously stated. Which means that, in the first place, the shared paradigm as well as the diversity must be kept in mind at the outset of any approach towards a policy for culture.

Its aim then should first be the common understanding of what is shared, and, second, the understanding and acceptance of the differences as a source of riches for everybody. Mutual knowledge and understanding could then start playing a political and social role in solving or at least living through the different problems and dangers of the coming century.

Finally, it should be understood that there can be a European framework, cultural institutions, funding, projects etc; but that there cannot be "a European product", a single "European" culture and the less art -- but only different creations, generated by the different cultures, with their own distinctions against the common and shared paradigm.

At this point, let me open a parenthesis. The subject which has to be considered is the one of so called high culture -- in opposition to mass culture. This culture and its products rarely reach -- at the moment of their creation -- more than one percent of the population. How many Germans read Goethe in their lifetime? Or Hawthorne, Melville, Thoreau, and Poe in America? One per cent? I doubt it. And how many Europeans listen to Mozart today, by their own choice? Two hundred years after Mozart, are they two or three per cent? There are many more similar examples.

What do I wish to say? That the number of those who are interested in the products of "high" culture is clearly disproportional in relation to its overall impact (and this includes of course philosophy, sociology, history and other disciplines in human sciences, and in another way natural sciences too). All this acquires a particular importance in our age, in the age of the audio-visual, however not only in relation to it. The public who listened to Mozart and read Goethe in their time is no more. Those who would read the Goethe of today do not have the means to sponsor him, and those who have the means do not listen to the Mozarts and the Beethovens of today. Precisely this fact acquires an enormous importance in the domain of the audio-visual. The main argument against for example the French-German cultural channel ARTE is that its audience does not exceed two per cent in France (where it is accessible publicly) and one per cent in Germany (where it is cabled). But nobody argues that this is likely more and sometimes much more than the percentage of audience reached by our cultural heritage since its creation thousands of years ago. Should, in the age of the audio-visual, the Europeans apply mass-audience criteria on their cultural output, we can 
rest assured that there would never be an audio-visual Rimbaud, nor Joyce, Proust, Kandinsky, and Bartók.

For, among others, the very simple reason that the small, restricted, linguistically limited European audiovisual markets do not compare with the American ones. On the other hand, the production costs of audiovisual art and other elements of high culture mostly do. (dominated by the American mass culture). The problem of publicly subsidized audiovisual culture and its distribution is thus of greatest importance for the very survival of the European national cultures in the age of the audiovisual.

This is why Europe needs the "cultural exception."

\section{Notes}

1.An authentic creator -- whether of "mass" or "high" culture is irrelevant -- is the one who can only imagine himself as his audience.

2. It is not by accident that so much of the American "high" culture and art has been created by dominated or otherwise excluded groups, such as Southerners or Jews.

\section{Author Information}

Anthony J. LIEHM, Czech journalist, film critic and film historian. After the Soviet-led invasion of Czechoslovakia in 1968 he left his native country to take up teaching and research at the CUNY, University of Pennsylvania, The English National Film School, the University of Paris and other institutions. His books in English include The Most Important Art: Soviet and East European Film After 1945; Closely watched Films and The Miloš Forman Stories. He is the editor of Lettre internationale (Paris) and now lives in Paris and Prague. 